\begin{tabular}{rr} 
çağdaş & Yaratıcı Drama Dergisi 2015, 10(2), 191-200 \\
drama & www.yader.org \\
\hline
\end{tabular}

\title{
Yaratıcı Drama Eğitiminin Ergenlerin Sosyal Becerilerine Etkisi
}

\author{
Seden Abaci ${ }^{1}$ \\ Kezban Tepeli \\ Filiz Erbay ${ }^{3}$
}

\begin{tabular}{|c|c|}
\hline Makale Bilgisi & $\ddot{\mathbf{O} z}$ \\
\hline DOI: $10.21612 /$ yader.2015.016 & Bu çalışma, ergenlere grupla bir işi yapma ve yürütme, ilişsiyi başlatma ve sürdürme \\
\hline $\begin{array}{l}\text { Anahtar Sözcükler } \\
\text { Yaratıcı drama } \\
\text { Ergen } \\
\text { Sosyal beceriler } \\
\text { Sosyal beceri ögrretimi }\end{array}$ & 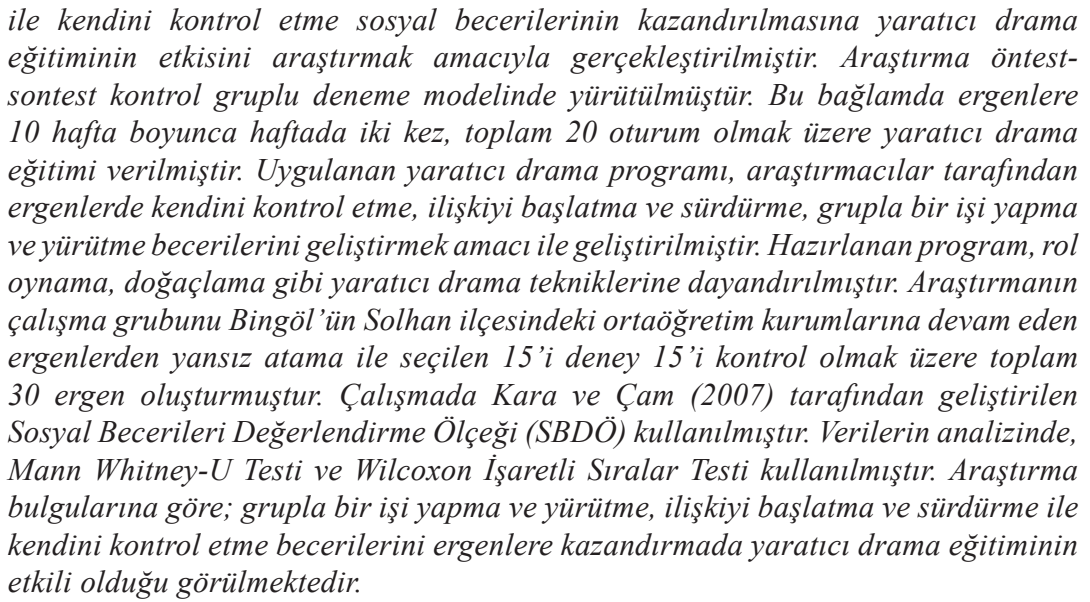 \\
\hline
\end{tabular}

\section{The Effect of Creative Drama Education on Social Skills of Adolescents}

\section{Article Info}

DOI: 10.21612 yader.2015.016

Keywords

Creative drama

Adolescent

Social skills

Social skills instruction

\begin{abstract}
This study was carried out to investigate the effect of creative drama education on making and executing a work with a group, beginning and maintaining relationship, and gaining social skills of self - control in adolescents. The research was designed as pretest-posttest control group in experimental model. In this context, creative drama education has been given to adolescents twice a week, for 10 weeks, a total of 20 sessions. The creative drama education program used in the study has been developed to evolve making and executing a work with a group, beginning and maintaining a relationship, and gaining social skills of self - control in adolescents by the researchers. This program was based on creative drama techniques such as, role play and improvisation. The working group of the research consisted of 30 adolescents attending to secondary school in Solhan Town placed in Bingol, including control of 15 selected randomly assigning 15 experiments. Social Skills Evaluation Scale (SBDÖ) developed by Kara ve Çam (2007) was used in the study. Mann Whitney-U Test and Wilcoxon Signed Rank Test were used in the analysis of the data. According to findings of the study, it is seen that creative drama education was effective on making and executing a work with a group, beginning and maintaining a relationship and gaining social skills of self - control in adolescents.
\end{abstract}

\footnotetext{
Uzman. MEB. Ali Kul Çok Programlı Lisesi, Çocuk Gelişimi ve Eğitimi Bölümü. Eposta: sedenabacii@gmail.com

2 Doç. Dr. Selçuk Üniversitesi, Sağlık Bilimleri Fakültesi, Çocuk Gelişimi Bölümü. Eposta:ktepeli@selcuk.edu.tr

3 Doç. Dr. Mevlana Üniversitesi Eğitim Fakültesi İlköğretim Bölümü, Okul Öncesi Öğretmenliği ABD., Eposta: ferbay@mevlana. edu.tr
} 


\section{Giriş}

Ergenlik dönemi, çocukluk ve erişkinlik arasında çeşitli fizyolojik, psikolojik ve sosyal değişikliklerin yaşandığı bir geçiş dönemi olması nedeniyle ergenin düşüncelerinde, duygularında ve davranışlarında dengesizliklere yol açan, firtınalı ve stresli bir dönemdir (Kulaksızoğlu, 1998). $\mathrm{Bu}$ dönemde yaşanan stres durumlarının etkilediği alanlardan biri de ergenlerin sosyal becerileridir.

Sosyal beceri, kişilerin başkaları ile olumlu etkileşimleri başlatmaları ve sürdürmeleri için önemli davranış elemanlarıdır (Westwood, 1993). Swindells ve Stagnitti (2006), sosyal becerilerin; sosyal durumlar ve sosyal düşüncelerle ilişkili beceriler olduğunu belirtirken, Cartledge ve Milburn (1983) sosyal becerileri; "başkalar ile etkileşimde olumsuz tepkileri önleyen ve olumlu tepkilerin verilmesine olanak taniyan, sosyal olarak uygun görülen, amaca yönelik sosyal bağlama bağl olarak değişiklik gösteren ve ayrıca duruma özgü olan davranışlar” olarak tanımlamaktadırlar (Akt. Kara ve Çam, 2007). Sosyal beceriler, bireylerin sosyal çevrelerinde sorunlarla karşılaşmaksızın, sosyal, fiziksel ve entelektüel gereksinimlerini karşılamalarına imkân tanıyan becerilerdir (Önder, 2003).

Günümüzde gerek akademik ortamlarda, gerek günlük yaşam içerisinde başarılı olabilmek için gerekli bilişsel yetilere ve yeteneklere sahip olmanın yanı sıra çeşitli sosyal becerilere sahip olmanın gerekliliği kaçınılmaz olarak düşünülmektedir (Palut, 2003). Sosyal beceriler, bireyin toplumsal yaşamda kabul görmesini ve çevreye uyum sağlamasını kolaylaştırmaktadır. Çevreye uyum sağlayan bireyler; başkalarıyla sağlıklı ilişkiler kurabilirler, işbirliği içerisinde çalışabilirler, başkalarının haklarına ve duygularına saygı duyabilirler, kendisi için uygun olmayan istekleri geri çevirebilirler ve gerektiğinde başkalarından yardım isteyebilirler (Ceylan, 2009; Yayla Ceylan, 2014). Dolayısıyla bireylerin mutlu, kendisiyle barışı, hedeflerini doğru tayin edebilen kişiler olmaları ve bu yolda çıkabilecek engellerle başa çıkabilmeleri için duygusal ve sosyal becerilere katkı sağlayacak tutum ve davranışların sergileneceği eğitim ortamlarının ve programlarının gerekliliği kaçınılmaz görünmektedir (Palut, 2003). Bu ortamlardan ve programlardan biri de yaratıcı drama uygulamalarıdır.

"Yaratıcı dramanın genel amacı, çocukların, ergenlerin ve gençlerin canlandırmalar yoluyla gerçek dünya ile kurgusal dünya arasında gidip gelmelerini olanaklı k1larak, bir bilinçlenme ve kültürlenme süreci içerisinde, her alanda yaratıcı, kendine yetebilen, kendini tanıyan, çevresiyle iletişim kurabilen ve bunu geliştirebilen, ifade gücü ve biçimleri artmış, imgesel düşünebilen, estetik kaygı, demokratik tutum ve davranışları gelişmiş bireyler yetiştirmektir”" (Adıgüzel, 2010).

Millî Eğitim Tebliğler Dergisi’nde (1998) drama yönteminin öğrencilerin; dil gelişimini sağladığı, birlikte çalışma, paylaşma, yardımlaşma isteğini artırdığı, kendi dünyasını arkadaşlarıyla paylaşıp sosyalleştiği, kendi duygu, ilgi, yetenek ve beklentilerini oyunlarında ortaya koyup, bedenini duygularını ifade etmede kullanmayı öğrettiği ifade edilmektedir.

Yaratıcı drama süreçleri, bireyin iletişim becerilerinin gelişmesine yardımcı olur ve kendini ifade etmesini kolaylaştırır. "Denilebilir ki dramanın doğasında etkileşim vardır. Etkileşim, daha çok, insanın insanla karşılaşmasında ortaya çıkan bir olgudur”. Yaratıcı drama öğrencilerde sosyal ve psikolojik duyarlılık yaratır, hata yapma korkusu olmaksızın yeni davranışlar geliştirmeyi sağlar. Kendini ifade etmede güven kazandırır, etik değerlerin gelişmesine olanak sağlar (San, 1996).

Yaratıcı dramada etkileşim, sosyal ilişkilerin güçlenmesine yardımcı olur. Üstündağ'a (1998) göre yaratıcı dramanın hedeflerinden biri de "kendine güven duyma ve karar verme becerileri 
kazanmadır. Kendine güven duyma, yaratıcı drama süreçleri ile sağlanabilir. Doğaçlamalar buna iyi bir örnek olarak verilebilir, çünkü doğaçlamalarda doğru ve yanlış yoktur. Bu durum da bireyde yanlış yapma korkusunu ortadan kaldırabilmektedir. Bu korkunun olmaması, bireyin yaratıcılığını ortaya koymasını ve geliştirmesini sağlayan bir özellik taşımaktadır (Okvuran, 2000).

Clark ve Fullwood (1994) yaptıkları çalışmada, işitme engellilerin sosyal beceri eğitiminde yapılandırılmış grup etkinliklerinden, görsel ögelerden, rol oynama ve mimik kullanımından hoşlandıklarını ve sosyal beceri eğitiminde bu etkinliklerin etkili olduğunu saptamışlardır. Clements ve Avery (1984), utangaç bireyler için sosyal beceri eğitimi programı geliştirmiş ve sonuçlar, utangaç bireylerin bu eğitimden sonra toplumsal durumlara katılım becerilerinin arttı̆̆ını göstermiştir. Alan yazın incelendiğinde, dramanın farklı örneklemlerde katılımcıların sosyal becerilerini desteklediğini gösteren çok sayıda araştırma olduğu dikkat çekmektedir. Bu araştırmalarda yaratıcı drama etkinliklerine katılan farklı yaş gruplarında engelli ve normal gelişim gösteren çocuk, ergen ve bireylerin sosyal gelişimlerinin ve becerilerinin gelişebileceği ortaya konmuştur (McCaslin, 2006; Freeman ve diğ., 2003; Akfırat, 2004, De La Cruz, 1995; Jackson ve Bynum, 1997; Kocayörük, 2000; Uysal, 1996; Johannsen, 2004; Yassa, 1997; Erbay ve Yıldırım Doğru, 2010).

$\mathrm{Bu}$ nedenle bu araştırmada, yaratıcı dramanın ergenlerin grupla bir işi yapma ve yürütme becerileri, ilişkiyi başlatma ve sürdürme becerileri ile kendini kontrol etme becerilerine etkisi olup olmadığı incelenmek istenmiştir. Alan yazında yer alan sosyal becerileri destekleyen yaratıcı drama çalışmalarından farklı olarak bu araştırmada; sosyal beceriler, grupla bir işi yapma ve yürütme becerileri, ilişkiyi başlatma ve sürdürme becerileri ile kendini kontrol etme becerileri olmak üzere üç alt boyutta ele alınmıştır. Ayrıca yapılan çalışmalar incelendiğinde, bu çalışmaların Türkiye'nin orta ve batı kesimlerinde yoğunlaşmış olduğu dikkat çekmektedir. Bu çalışma Türkiye'nin daha doğu bölgelerinde farklı sosyal ve kültürel özelliklerin sergilendiği bir bölgede yapılmış olması bakımından da alan yazında yer alan diğer araştırmalardan farklılık göstermektedir. Araştırmanın bu açılardan önem arz ettiği, farklı sosyal ve kültürel ortamlarda yapılacak çalışmalara katkı sağlayacağı düşünülmektedir.

$\mathrm{Bu}$ doğrultuda araştırmanın genel amacı; ergenlerin grupla bir işi yapma ve yürütme becerileri, ilişkiyi başlatma ve sürdürme becerileri ile kendini kontrol etme becerilerine yaratıcı drama eğitiminin etkisini ortaya koymaktır.

\section{Yöntem}

\section{Araştırmanın Modeli}

$\mathrm{Bu}$ araştırma; ergenlerin sosyal beceri düzeylerinin, yaratıcı drama değişkenine bağlı olarak farklılaşıp farklılaşmadığını test etmek amacı ile hazırlanmış, öntest-sontest kontrol gruplu deneme modelinde bir çalışmadır.

$\mathrm{Bu}$ araştırmanın bağımsız değişkeni, ergenlere verilen yaratıcı drama eğitimi; bağımlı değişkeni, sosyal becerilerdir. Araştırma, bağımsız değişkenin bağımlı değişkenler grubunu etkileyip etkilemediğini ortaya koyacak modelde desenlenmiştir. 10 haftalık deneme sürecinden sonra deneme grubuna eğitimin (bağımsız değişkenin) etkisini test etmek amacıyla sontest uygulanmıştır. 


\section{Çalışma Grubu}

Araştırmanın çalışma grubunu belirlemek amacıyla öncelikle Bingöl İli; Solhan ilçe Milli Eğitim Müdürlüğü’ne bağl1, ortaöğretim kurumlarına devam eden 120 öğrenciye 'Sosyal Becerileri Değerlendirme Ölçeği' (SBDÖ) uygulanmıştır. Ölçekten düşük puan alan 30 öğrenci belirlenmiştir. Bu öğrencilerin 10'u erkek 20'si ise kızdır. Yansız atama yolu ile bu öğrencilerin 15'i kontrol 15'i deney grubu olarak belirlenmiştir. Deney ve kontrol grubu öğrencilerin 10'u kız 5'i ise erkektir.

\section{Veri Toplama Araçları}

Araştırmada yaratıcı drama yönteminin uygulandığı deney ve kontrol gruplarındaki öğrencilerin sosyal beceri düzeylerini ölçmek için, ‘Sosyal Becerileri Değerlendirme Ölçeği’ (SBDÖ) kullanılmıştır.

Sosyal Becerileri Değerlendirme Ölçeği (SBDÖ): Sosyal becerileri değerlendirme ölçeği (SBDÖ), sosyal etkileşimi arttırmak için iletişim yetersizliklerine yardım etmede önemli olan becerileri ölçmeyi amaçlamaktadır. SBDÖ, 17-25 yaşlarındaki genç yetişkinlerin sahip olması gereken sosyal becerileri içermektedir. SBDÖ, 15 madde ve üç alt ölçekten oluşan, beşli derecelendirmeli, likert tipi bir ölçme aracıdır. Alt ölçekler; grupla bir işi yapma ve yürütme becerileri, ilişkiyi başlatma ve sürdürme becerileri ile kendini kontrol etme becerileridir. Her bir alt ölçek, beşer maddeden oluşmaktadır. Maddelerin tamamı olumlu yönde düzenlenmiştir. Maddelere verilen tepkiler; "kesinlikle katılmıyorum", "katılmıyorum", "kararsızım", "katılıyorum" ve "kesinlikle katılıyorum" şeklinde derecelendirilmiştir. Kesinlikle katılmıyorum cevabı 1, kesinlikle katılıyorum cevabı 5 puan almaktadır. Düşük puan, sosyal becerilere yeterince sahip olunmadığını, yüksek puan ise sosyal becerilere sahip olunduğunu göstermektedir. Ölçekten alınabilecek en düşük puan madde sayısı olan 15 iken, en yüksek puan 75 puandır. Alt ölçeklerin her birinden en az 5 en çok 25 puan alınabilmektedir (Kara ve Çam, 2007).

\section{İşlem}

Çalışmada yaratıcı drama yöntemi kullanılarak ergenlerin grupla bir işi yapma ve yürütme, ilişkiyi başlatma ve sürdürme ile kendini kontrol etme sosyal becerilerinin geliştirilmesi amaçlanmıştır. Ergenlerin sosyal beceri düzeylerinin yaratıcı drama değişkenine bağlı olarak farklılaşıp farklılaşmadığını test etmek üzere, deney ve kontrol grubu oluşturulmuştur. Yaratıcı drama eğitim programı, lise dönemindeki ergenlerin sosyal becerilerinin kazandırılmasını esas almaktadır. 10 hafta süren programın etkililiğini ölçebilmek için deney ve kontrol grubuna eş zamanlı olarak SBDÖ yaratıcı drama uygulamaların öncesinde öntest ve yaratıcı drama uygulamalarının sonrasında da sontest olarak uygulanmıştır. Araştırmacılar tarafından hazırlanan yaratıcı drama programı ile ergenlerin çeşitli durumlarda rol oynamaları, duygu ve düşüncelerini açıklamaları sağlanarak sosyal becerilerini arttırmak hedeflenmiştir.

Yaratıcı drama eğitim programı planlanırken sosyal becerileri değerlendirme ölçeğinden elde edilen veriler çalışmanın kazanımları olarak belirlenmiştir. Programın ilk uygulamalarında 1sınma çalışmalarına yer verilerek ergenlerin kendilerine, birbirlerine, mekâna, drama liderine 1sınmaları ve güven geliştirmeleri amaçlanmıştır, böylelikle ergenler bir sonraki çalışma için hazır hale getirilmiştir. Isınma çalışmalarından sonra rol oynama ve doğaçlama çalışmalarına yer verilmiştir. Rol oynama ve doğaçlama çalışmaları ile ergenlerin; ilişkiyi başlatma, sürdürme, kendini kontrol etme gibi sosyal becerilerinin karşılıklı konuşmalarla yeni durumlara uyarlamaları amaçlanmıştır. 
Çalışmaların sonunda yapılan ve o günkü kazanımlarla ilgili dönüt alınan değerlendirme aşamasında, ergenlere basit, anlaşılır ve açık uçlu sorular sorularak atölye kazanımları değerlendirilmiştir.

\section{Verilerin Toplanması ve Analizi}

Deneme ve kontrol gruplarına "SBDÖ" ön test ve son test olarak uygulanmıştır. Araştırmacılar ölçekle ilgili bilgileri ergenlere açıklamış ve her ergen ölçeğini bireysel olarak kendisi doldurmuştur. Araştırma kapsamında kontrol ve deney grubu arasında uygulama öncesinde ve sonrasındaki farklılıkları karşılaştırmak amacıyla SBDÖ aracılı̆̆ Paket Programı yardımıyla analiz edilmiştir. SBDÖ elde edilen verilerin analizinde; Mann Witney U analizi, Wilcoxon İşaretli Sıralar Testi kullanılmıştır. Karşılaştırmalarda 0.05 düzeyinde anlamlılık aranmıştır.

\section{Bulgular}

Ergenlerin sosyal beceri düzeylerine yaratıcı dramanın etkisini incelenmek amacıyla yapılan araştırmada deneme ve kontrol gruplarının SBDÖ bulgularına ait tablolar aşağıda verilmiştir.

Tablo 1. Deneme ve Kontrol Grubunu Oluşturan Ergenlerin Sosyal Becerileri Değerlendirme Ölçeği alt Ölçek ve Toplam Ölçek Öntest Puanlarına Göre Mann Witney U Testi Sonuçları

\begin{tabular}{|c|c|c|c|c|c|c|c|c|}
\hline & Grup & $\mathbf{n}$ & $\mathbf{x}$ & $\mathbf{S}$ & Sira Ortalaması & Sıra Toplamı & $\mathbf{U}$ & $\mathbf{p}$ \\
\hline \multirow{2}{*}{$\begin{array}{l}\text { Kendini Kontrol } \\
\text { Etme Becerileri }\end{array}$} & Deneme & 15 & 16.73 & 3.94 & 14.57 & 218.50 & \multirow[t]{2}{*}{98.500} & 0.567 \\
\hline & Kontrol & 15 & 17.67 & 2.55 & 16.43 & 246.50 & & $\mathrm{p}>0.05$ \\
\hline \multirow{2}{*}{$\begin{array}{l}\text { İlişkiyi Başlatma } \\
\text { ve Sürdürme } \\
\text { Becerileri }\end{array}$} & Deneme & 15 & 15.67 & 3.35 & 12.63 & 189.50 & \multirow[t]{2}{*}{69.500} & 0.074 \\
\hline & Kontrol & 15 & 17.60 & 1.96 & 18.37 & 275.50 & & $\mathrm{p}>0.05$ \\
\hline \multirow{2}{*}{$\begin{array}{l}\text { Grupla Bir } \\
\text { Işi Yapma } \\
\text { ve Yürütme } \\
\text { Becerileri }\end{array}$} & Deneme & 15 & 15.60 & 3.56 & 14.43 & 216.50 & \multirow[t]{2}{*}{96.500} & 0.512 \\
\hline & Kontrol & 15 & 16.40 & 2.25 & 16.57 & 248.50 & & $\mathrm{p}>0.05$ \\
\hline \multirow{2}{*}{$\begin{array}{l}\text { Sosyal Becerileri } \\
\text { Değerlendirme } \\
\text { Ölçeği (Toplam) }\end{array}$} & Deneme & 15 & 48.00 & 8.91 & 13.87 & 208.00 & \multirow[t]{2}{*}{88.000} & 0.325 \\
\hline & Kontrol & 15 & 51.67 & 5.35 & 17.13 & 257.00 & & $\mathrm{p}>0.05$ \\
\hline
\end{tabular}

Tablo 1'e göre deneme ve kontrol gruplarının sosyal becerileri değerlendirme ölçeği ve alt ölçek öntest puanları arasında istatistiksel olarak anlamlı bir fark bulunmamıştır. Alt ölçekler incelendiğinde kendini kontrol etme becerileri ( $U=98.500$ p>.05), ilişkiyi başlatma ve sürdürme becerileri ( $U=69.500, p>.05)$, grupla bir işi yapma ve yürütme becerileri ( $U=96.500 \mathrm{p}>.05)$ ve sosyal becerileri değerlendirme ölçeği toplamının $(U=88.000$ p>.05) olduğu sonucuna varılmıştır. Sıra ortalamaları ve sıra toplamları dikkate alındığında hesaplanan bu değerler yaratıcı drama eğitimine katılan ve katılmayan ergenlerin sosyal beceri değerlendirme ölçeği öntest puanlarının benzer olduğuna işaret etmektedir. 
Tablo 2. Deneme ve Kontrol Grubunu Oluşturan Ergenlerin Sosyal Becerileri Değerlendirme Ölçeği alt Ölçek ve Toplam Ölçek Sontest Puanlarına Göre Mann Witney U Testi Sonuçları

\begin{tabular}{lcccccccc}
\hline & Grup & $\mathbf{n}$ & $\mathbf{x}$ & $\mathbf{S}$ & $\begin{array}{c}\text { Sıra } \\
\text { Ortalaması }\end{array}$ & $\begin{array}{c}\text { Sıra } \\
\text { Toplamı }\end{array}$ & $\mathbf{U}$ & $\mathbf{p}$ \\
\hline $\begin{array}{l}\text { Kendini Kontrol } \\
\text { Etme }\end{array}$ & Deneme & 15 & 20.67 & 3.60 & 19.03 & 285.50 & & 0.026 \\
$\begin{array}{l}\text { Becerileri } \\
\text { Kontrol }\end{array}$ & 15 & 17.93 & 3.53 & 11.97 & 179.50 & 59.500 & $\mathrm{p}<0.05$ \\
\hline $\begin{array}{l}\text { İlişkiyi Başlatma } \\
\text { ve Sürdürme }\end{array}$ & Deneme & 15 & 22.40 & 1.84 & 22.63 & 339.50 & 5.500 & 0.000 \\
$\begin{array}{l}\text { Becerileri } \\
\text { Krupla Bir işi }\end{array}$ & Kontrol & 15 & 16.13 & 2.70 & 8.37 & 125.50 & & $\mathrm{p}<0.001$ \\
$\begin{array}{l}\text { Yapma ve Yürüitme } \\
\text { Becerileri }\end{array}$ & Kontrol & 15 & 17.93 & 3.92 & 10.27 & 154.00 & 34.000 & 0.001 \\
\hline $\begin{array}{l}\text { Sosyal Becerileri } \\
\text { Değerlendirme } \\
\text { Ölçeği (Toplam) }\end{array}$ & Deneme & 15 & 65.53 & 5.30 & 22.10 & 331.50 & & $\mathrm{p}<0.01$ \\
\hline
\end{tabular}

Tablo 2 incelendiğinde, deneme ve kontrol gruplarının sosyal becerileri değerlendirme ölçeği ve alt ölçeği sontest puanları istatistiksel olarak anlamlı düzeyde farklılaşmaktadır. Alt ölçekler incelendiğinde kendini kontrol etme becerileri ( $U=59.500 \mathrm{p}<.05)$, ilişkiyi başlatma ve sürdürme becerileri $(U=5.500, p<.01)$, grupla bir işi yapma ve yürütme becerileri $(U=34.000 p<.01)$ ve sosyal becerileri değerlendirme ölçeği toplamının $(U=13.500 \mathrm{p}<.01)$ olduğu sonucuna varılmıştır. Sıra ortalamaları ve sıra toplamları dikkate alındığında yaratıcı drama eğitimine katılan deneme grubu ergenlerin sosyal beceri değerlendirme ölçeği sontest puan ortalamaları, yaratıcı drama eğitimine katılmayan kontrol grubu ergenlerin sosyal beceri değerlendirme ölçeği sontest puan ortalamalarından daha yüksek olduğu anlaşılmaktadır. Bu bulgu, yaratıcı drama eğitiminin ergenlerin kendini kontrol etme, ilişkiyi başlatma ve sürdürme, grupla bir işi yapma ve yürütme becerileri ile sosyal becerilerini desteklediğini göstermektedir.

Tablo 3. Deneme Grubunu Oluşturan Ergenlerin Sosyal Becerileri Değerlendirme Ölçeği alt Ölçek ve Toplam Ölçek Öntest- Sontest Puanlarının Wilcoxon Işsaretli Stralar Testi Sonuçları

\begin{tabular}{|c|c|c|c|c|c|c|}
\hline & Sontest- Öntest & $\mathbf{n}$ & $\begin{array}{l}\text { Sira } \\
\text { Ortalaması }\end{array}$ & Sira Toplamı & $\mathbf{Z}$ & $\mathbf{p}$ \\
\hline Kendini Kontrol & Negatif Sira & 1 & 12.00 & 12.00 & \multirow{3}{*}{-2.731} & \multirow{3}{*}{$\begin{array}{l}0.006 \\
p<0.01\end{array}$} \\
\hline Etme & Pozitif Sıra & 14 & 7.71 & 108.00 & & \\
\hline Becerileri & Eşit & 0 & & & & \\
\hline İlişkiyi Başlatma & Negatif Sira & 0 & 0.00 & 0.00 & \multirow{3}{*}{-3.300} & \multirow{3}{*}{$\begin{array}{l}0.001 \\
p<0.01\end{array}$} \\
\hline ve Sürdürme & Pozitif Sira & 14 & 7.50 & 105.00 & & \\
\hline Becerileri & Eşit & 1 & & & & \\
\hline Grupla Bir Işi & Negatif Sira & 1 & 1.50 & 1.50 & & \multirow{3}{*}{$\begin{array}{l}0.001 \\
p<0.01\end{array}$} \\
\hline Yapma ve Yürütme & Pozitif Sıra & 14 & 8.46 & 118.50 & -3.328 & \\
\hline Becerileri & Eşit & 0 & & & & \\
\hline
\end{tabular}




\begin{tabular}{|c|c|c|c|c|c|c|}
\hline Sosyal Becerileri & Negatif Sira & 0 & 0.00 & 0.00 & & 0001 \\
\hline Değerlendirme & Pozitif Sıra & 15 & 8.00 & 120.00 & -3.410 & \\
\hline Ölçeği (Toplam) & Eşit & 0 & & & & $\mathrm{p}<0.01$ \\
\hline
\end{tabular}

Tablo 3’te de görüldüğü üzere, deneme grubu ergenlerinin sosyal beceri değerlendirme ölçeği öntest-sontest puanları arasında istatistiksel olarak anlamlı bir fark bulunmuştur. Alt ölçekler incelendiğinde kendini kontrol etme becerileri $(Z=-2.731, p<0.01)$, ilişkiyi başlatma ve sürdürme becerileri ( $Z=-3.300, p<0.01$ ), grupla bir işi yapma ve yürütme becerileri ( $Z=-3.328, p<0.01)$, ve sosyal becerileri değerlendirme ölçeği toplamının $(Z=-3.410, p<0.01)$ olduğu sonucuna varılmıştır. Fark puanlarının sıra ortalaması ve toplamları dikkate alındığında, yaratıcı drama eğitiminin deneme grubu ergenlerin sosyal davranışları üzerinde önemli bir etkisinin olduğu söylenebilir.

Tablo 4. Kontrol Grubunu Oluşturan Ergenlerin Sosyal Becerileri Değerlendirme Ölçeği alt Ölçek ve Toplam Ölçek Öntest- Sontest Puanlarının Wilcoxon İşaretli Sıralar Testi Sonuçları

\begin{tabular}{|c|c|c|c|c|c|c|}
\hline & Sontest- Öntest & $\mathbf{n}$ & Sira Ortalaması & Sira Toplamı & $\mathbf{Z}$ & $\mathbf{p}$ \\
\hline Kendini Kontrol & Negatif Sira & 6 & 5.42 & 32.50 & \multirow{3}{*}{-0.515} & \multirow{3}{*}{$\begin{array}{c}0.607 \\
p>0.05\end{array}$} \\
\hline Etme & Pozitif Sura & 6 & 7.58 & 45.50 & & \\
\hline Becerileri & Eşit & 3 & & & & \\
\hline İlişkiyi Başlatma & Negatif Sira & 9 & 7.17 & 64.50 & \multirow{3}{*}{-1.918} & \multirow{3}{*}{$\begin{array}{c}0.064 \\
p>0.05\end{array}$} \\
\hline ve Sürdürme & Pozitif Sura & 3 & 4.50 & 13.50 & & \\
\hline Becerileri & Eşit & 3 & & & & \\
\hline Grupla Bir Işi & Negatif Sira & 5 & 5.40 & 27.00 & \multirow{3}{*}{-1.302} & \multirow{3}{*}{$\begin{array}{c}0.193 \\
\mathrm{p}>0.05\end{array}$} \\
\hline Yapma ve Yürütme & Pozitif Sura & 8 & 8.00 & 64.00 & & \\
\hline Becerileri & Eşit & 2 & & & & \\
\hline Sosyal Becerileri & Negatif Sira & 7 & 5.29 & 37.00 & \multirow{3}{*}{-0.158} & \multirow{3}{*}{$\begin{array}{l}0.875 \\
\mathrm{p}>0.05\end{array}$} \\
\hline Değerlendirme & Pozitif Sıra & 5 & 8.20 & 41.00 & & \\
\hline Ölçeği (Toplam) & Eşit & 3 & & & & \\
\hline
\end{tabular}

Tablo 4'de yer verildiği gibi kontrol grubu ergenlerin sosyal beceri değerlendirme ölçeği öntest- sontest puanları arasında istatistiksel olarak anlamlı bir fark bulunmamıştır. Alt ölçekler incelendiğinde kendini kontrol etme becerileri $(Z=-0.515, \mathrm{p}<0.05)$, ilişkiyi başlatma ve sürdürme becerileri $(Z=-1.918, p<0.05)$, grupla bir işi yapma ve yürütme becerileri $(Z=-1.302, p<0.05)$ ve sosyal becerileri değerlendirme ölçeği toplamının $(Z=-0.158, p<0.05)$ olduğu sonucuna varılmıştır. Fark puanlarının sıra ortalaması ve toplamları dikkate alındığında, kontrol grubu ergenlerin sosyal davranışlarında bir gelişme olmadığı görülmüştür.

\section{Tartışma}

$\mathrm{Bu}$ çalışmada yaratıcı drama eğitiminin ergenlerin grupla bir işi yapma ve yürütme becerileri, ilişkiyi başlatma ve sürdürme becerileri, kendini kontrol etme becerileri ile ilgili sosyal becerileri üzerine etkisi test edilmiştir. Çalışma sonucunda, insan davranışlarında etkili ve kalıcı bir yöntem olarak kullanılan dramanın, ergenlerin sosyal becerileri üzerinde etkili olduğu görülmüştür. Yaratıcı drama eğitim programına katılan ergenlerin rol oynama, doğaçlama gibi çalışmalarla farklı rollere girmeleri, grup etkinlikleri ve doğaçlamalara katılmaları, değerlendirme çalışmaları ile duygu ve 
düşüncelerini ifade etme firsatı bulmaları sayesinde sosyal becerilerinde olumlu değişiklikler meydana gelmiştir. Bu bağlamda, deney grubundaki öğrencilerin sosyal becerilerinde, kontrol gruplarındaki öğrencilere göre daha fazla gelişme olduğu bulunmuştur.

Alan yazın incelendiğinde bu konuda yapılan farklı çalışma sonuçlanının olduğu dikkat çekmektedir. Kara ve Çam (2007) çalışmalarında, gelişim ve öğrenme dersine devam eden öğretmen adaylarının grupla bir işi yapma ve yürütme, ilişkiyi başlatma ve sürdürme ile kendini kontrol etme gibi sosyal becerilerini desteklemede yaratıcı drama yönteminin etkili olduğu sonucunu ortaya koymuşlardır. Kara ve Çam (2007)' in çalışma sonuçları, bu araştırmanın sonucu ile örtüşmekte ve bu araştırmadan elde edilen sonuçları desteklemektedir.

Alan yazında farklı araştırmacılar tarafından, farklı örneklem grupları ile yapılmış çalışmalar ve bu araştırma bulgularını destekler sonuçlar mevcuttur. Bu araştırmalarda, farklı yaş gruplarıyla gerçekleştirilen yaratıcı drama uygulamalarının sosyal gelişim ve sosyal becerilerin gelişimine katkı sağladığına ilişkin sonuçlara yer verilmiştir. Bu çalışmalarda yaratıcı dramanın; Güner (2008), beşaltı yaş çocuklarının sosyal duygusal uyum düzeylerini; Bayrakçı (2007), okul öncesi dönemdeki çocukların iletişim becerilerini; Catterall (2007), çocukların grupla çalışma, problem çözme becerisini; Uşaklı (2006), ilköğretim beşinci sınıf öğrencilerinin arkadaşlık ilişkilerini ve benlik saygılarını; Bayer (2006), 7-16 yaş arasında olan 22 sokak çocuğunun iletişim becerilerini; Kamaraj (2004), beş yaşındaki çocukların atılganlık sosyal becerisini; AnnGuli (2004), 8-14 yaş çocuklarının sosyal becerilerini; Akfırat (2004), işitme engellilerin sosyal becerilerini desteklediğini belirtmişlerdir.

Çalışma sonuçlarında yer verildiği gibi, yaratıcı drama eğitimine katılan çocukların ve ergenlerin bazı sosyal davranışlarında olumlu yönde değişiklikler gözlenmektedir. Bu da yaratıcı drama eğitiminin ergenlerde ve farklı yaş gruplarında sosyal gelişim ve sosyal becerilerin desteklenmesinde önemli bir yere sahip olduğunu göstermektedir.

\section{Sonuç ve Öneriler}

$\mathrm{Bu}$ araştırmanın sonuçları, yaratıcı drama eğitimin sosyal becerileri desteklediğini göstermiştir. $\mathrm{Bu}$ sonuç doğrultusunda aşağıdaki öneriler geliştirilebilir. Yaratıcı drama grup içi etkileşime dayalı bir yöntem olduğundan dolayı her yaş grubundan katılımcıların sosyal becerilerini desteklemek amacıyla yöntem olarak etkili bir şekilde kullanılabilir. Bu nedenle öğretmenlerin bu konudan haberdar olmaları ve eğitim süreci içinde yaratıcı dramayı bir yöntem olarak kullanabilmeleri için öğretmen yetiştiren lisans programlarında yaratıcı drama ve eğitimde drama ile ilgili derslere yer verilmelidir.

Öğretmenlerin sosyal becerileri oluşturan değişkenlere bir bütün olarak sahip olmaları, ergenlerin, sınıf ve rehber öğretmenleri tarafından ergenlik dönemi sosyal davranış özellikleri hakkında bilgilendirilmeleri ve bu yolla ergenlerin yetersiz davranışlarının tespit edilebilmesi önem arz etmektedir. 


\section{Kaynakça}

Adıgüzel, Ö. (2010). Eğitimde yaratıcı drama, Ankara: Naturel Yayınevi.

Akfırat, Ö. F. (2004). Yaratıcı dramanin işitme engellilerin sosyal becerilerinin gelişimine etkisi. Yayımlanmamış yüksek lisan tezi, Ankara Üniversitesi Sosyal Bilimler Enstitüsü Özel Eğitim Anabilim Dalı, Ankara.

AnnGuli, L. (2004). The effects of creative drama-based intervention for children with deficits in social perception. Austin: Ph.D Thesis, The University of Texas.

Bayer, M. (2006). Sokak çocuklarının eğitiminde drama ve tiyatronun kullanılması ve bir uygulama. Yayınlanmamış yüksek lisans tezi, Ankara Üniversitesi Sosyal Bilimler Enstitüsü, Ankara.

Bayrakçı, M. (2007). Okulöncesinde yaratıcı drama etkinliklerinin iletişsim becerilerinin gelişmesi üzerindeki etkisi. Yayınlanmamış yüksek lisans tezi, Kars Kafkas Üniversitesi Sosyal Bilimler Enstitüsü, Kars.

Catterall, J. S. (2007). Enhancing peer conflict resolution skills through drama: An experimental study. Research in Drama Education.12(2):163-178.

Ceylan, Ş. (2009). Vineland sosyal duygusal erken çocukluk ölçeğinin geçerlik ve güvenirlik çalışması ve okul öncesi eğitim kurumuna devam eden beş yaş çocuklarının sosyal-duygusal davranışlarına yaratıcı drama eğitiminin etkisinin incelenmesi. Yayımlanmamış doktora tezi, Ankara Gazi Üniverisitesi Eğitim Bilimleri Enstitüsü, Ankara.

Clark, P.\&Fullwood, L. (1994). Social skills activities touse with hearing impaired children. Journal British Assn. Teachers of The Deaf, 18(3), 86-94.

Clements,L.A., Avery W.(1984), Acognitive behavioral approach to social skills training with shy persons, Journal of ClinicalPsychology, 40, 710-719.

De La Cruz, R. E. (1995). The effects of creative drama on the social and oral language skills of children with learning disabilities, Ph.DThesis, İlllinoisStateUniversity, Bloomington.

Erbay, F. ve Yıldırım Doğru, S. S. (2010). The effectiveness of creative drama education on the teaching of social communication skills in main streamed students Procedia Social and Behavioral Sciences, 2, $4475-4479$.

Freeman, G. D. Sullivan, K. Fulton, C. R. (2003). Effects of creative drama on selfconcept, social skills, and problem behavior. Journal of Educational Research. 96 (3), 131-138.

Güner, A. Z. (2008). Eğitici drama uygulamalarının 5-6 yaş grubu çocukların sosyal-duygusal uyumlarına etkisinin incelenmesi. Yayınlanmamış yüksek lisans tezi, İstanbul Marmara Üniversitesi, Eğitim Bilimleri Enstitüsü, İstanbul.

Jackson,T.\&Bynum,N.A.(1997).Teaching toolfor culturally diverse children with behavioral disorders. Journal of InstructationPsychology, 23, 6-18.

Johannsen, K. C. P. (2004). Social issue drama and its impact on the social consciousness of preadolescent school children. Unpublished Doktoral Dissertation, University of St. Thomas. St.Paul-Minnesota.

Kamaraj, I. (2004). Sosyal becerileri derecelendirme ölçeğinin Türkçeye uyarlanması ve beş yaş çocuklarının atılganlık sosyal becerisini kazanmalarında eğitici drama programının etkisi. Yayınlanmamış doktora tezi, Marmara Üniversitesi Eğitim Bilimleri Enstitüsü, İstanbul.

Kara, Y. ve Çam, F. (2007). Yaratıcı drama yönteminin bazı sosyal becerilerin kazandırılmasına etkisi. Hacettepe Üniversitesi Eğitim Fakültesi Dergisi, 32, 145-155.

Kulaksızoğlu, A., (1998). Ergenlik psikolojisi, İstanbul: Remzi Kitabevi.

Kocayörük, A. (2004). Duygusa zeka eğitiminde drama etkinlikleri. Ankara: Nobel Yayınları.

McCaslin, N. (2006). Creative drama in theclassroom and beyond. USA: Pearson Education.

Milli Eğitim Bakanlığı (1998). Tebliğler Dergisi, s.1080.

Okvuran, A. (2000). Yaratıcı dramaya yönelik tutumlar. Yayımlanmamış doktora tezi, Ankara Üniversitesi Sosyal Bilimler Enstitüsü.

Önder, A. (2003). Okul öncesi çocuklar için eğitici drama uygulamaları. İstanbul: Morpa Kültür Yay. 
Palut, B. (2003). Sosyal gelişim ve arkadaşlık ilişkileri. M. Sevinç (ed.). Erken çocuklukta gelişsim ve eğitimde yeni yaklaşımlar. (ss.311-318). İstanbul: Morpa Kültür Yayınları

San, İ. (1996). Yaratııılığı geliştiren bir yöntem ve yaratıcı bireyi yetiştiren bir disiplin: Eğitsel yaratıcı drama. Yeni Türkiye Dergisi. 2 (7), 148-160.

Swindells, D. ve Stagnitti, K. (2006). Pretened play and parents' view of social competence: the construct validity of the child- Initiated pretend play assessment. Australian Occupational Therapy Journal. 53, 314-324.

Uşakl1, H. (2006). Drama temelli grup rehberliğinin ilköğretim 5. sınlf öğrencilerinin arkadaşlı ilişkileri, atılganlık düzeyi ve benlik saygısına etkisi. Yayınlanmamış doktora tezi, Dokuz Eylül Üniversitesi Eğitim Bilimleri Enstitüsü, İzmir.

Uysal, F. N. (1996). Anaokuluna giden 5-6 yaş grubu çocuklarda yaratıcı drama çalı̧̧malarının sosyal gelişim alanına olan etkisinin incelenmesi. Yayınlanmamış yüksek lisans tezi. Ankara Üniversitesi Sosyal Bilimler Enstitüsü, Ankara.

Üstündağ, T. (1998). Yaratıcı drama eğitim programının öğeleri. Eğitim ve Bilim Dergisi, 107, 30-37.

Westwood, P. (1993). Common sense methods for children with special needs strategies for the regular classrom. London.

Yassa, N. A. (1997). A study of the effect of drama education on social interaction in high school students. Unpublished Doktoral Dissertation, Lakehead University, Ontario.

Yayla Ceylan, Ş. (2014). Dramatik etkinlikler ve dramanın çocuğun gelişimindeki yeri. E. Ömeroğlu (ed.). Okul öncesi eğitimde dramatik etkinliklerden dramaya teoriden uygulamaya (4.bs.) Ankara: Eğitenkitap. 